\title{
ІНФОРМАЦІЙНА СИСТЕМА ТУРБІННОГО ЦЕХУ У СКЛАДІ СИСТЕМИ КЕРУВАННЯ ТЕПЛОВОЇ ЕЛЕКТРОСТАНЦІЇ ЦУКРОВОГО ЗАВОДУ
}

\author{
Скаковський Ю.М., Бабков А.В., Мандро О.Ю. \\ Одеська національна академія харчових технологій, Одеса, Україна \\ ORCID: ${ }^{1}$ 0000-0003-4888-4469; ${ }^{2}$ 0000-0002-9167-7804 \\ E-mail: yurysk@ukr.net, babandval@gmail.com, beautyouare@gmail.com \\ Copyright (C) 2018 by author and the journal "Automation technologies and business - processes. \\ This work is licensed under the Creative Commons Attribution International License (CC BY). \\ http://creativecommons.org/licanses/by/4.0
}

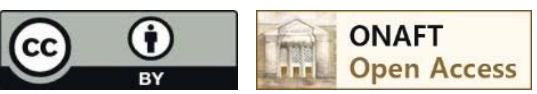

DOI: $10.15673 /$ atbp.v10i1.874

Анотація: Розглядаються технічні рішення з розробки інформаційно-керуючої системи турбінного изеху, яка, сумісно з раніше розробленої інформаційної системи котельного відділення, є складовою частиною системи керування теплової електростаниії иукрового заводу. Система побудована як автоматизоване робоче місие (АРМ) оператора на базі комп'ютера, мережі мікропрочесорних контролерів та регуляторів, датчиків та виконавчих механізмів. Мережа мікропроцесорних контролерів та регуляторів реалізована на базі перетворювача MODBUS RTU - USB типу БПI-52. АРМ включає також щчит оператора для реалізації дистанційного режиму керування. На фронтальній стороні щита розташовані мікропроцесорні контролери, а також прилади, щзо показують, та органи дистанційного керування. На внутрішніх панелях щчита розташована група клемно-блочних з'єднувачів та приладів системи живлення. Інформаційна система спроектована з використанням мікропроцесорних контролерів, приладів $i$ SCADA украӥнського виробниитва. Імітаиійне моделювання проводилося на спеціалізованому стенді із застосуванням промислових контролерів і програм. Результати досліджень застосовані для модернізації інформаційно-керуючої системи турбінного ичеху иукрового заводу.

Abstract: The technical solutions for the development of the turbine department information-control system are considered, which is, in combination with the previously developed information system of the boiler department, an integral part of the control system of the sugar plant thermal power station. The system is built as an automated workplace (AWS) of the operator on the basis of the computer, network of microprocessor controllers and regulators, sensors and actuators. The network of microprocessor controllers and regulators is launched on the basis of MODBUS RTU-USB converter BPI-52 type. Workstation also includes operator panel to implement remote control mode. On the front side are microprocessor controllers, as well as display devices, and remote control units. On the inner panels of the shield there is a group of terminal block connectors and power supply devices. The control system is designed using microprocessor controllers, devices and programs of Ukrainian production. Simulation modeling was conducted on specialized stand with the use of industrial controllers and programs. The research results are applied for the modernization of the information and control system of the turbine shop of the sugar plant.

Ключові слова: Система автоматичного керування, автоматизоване робоче місце оператора, мікропроцесорний контролер, турбінний цех, цукровий завод.

Keywords: System of automatic control, workstation of operator, microprocessor-based comptroller, turbine workshop, sugar plant.

Вступ

В Одеській національній академії харчових технологій у рамках госпдоговірної тематики виконуються роботи 3 надання науково-технічної допомоги при модернізації систем автоматизації для підвищення ефективності їхнього функціонування на Красилівському бурякоцукровому заводі (Хмельницької області). Створена багаторівнева автоматизована система керування технологічними процесами (АСКТП) бурякоцукрового виробництва, що включає автоматизовані робочі місця (АРМ) операторів основних технологічних ділянок, АРМи диспетчера, головного технолога й директора на базі мікропроцесорних контролерів, комп'ютерів і локальної мережі на базі технології Ethernet [1]. У цей час виконані роботи з модернізації системи автоматизації турбінного цеху, що включена в інформаційно-керуючу систему ТЕЦ. 


\section{Аналіз літературних джерел і постановка проблеми}

Відомі програмні комплекси, наприклад, інноваційна система керування процесом SIMATIC PCS 7 компанії Siemens, яка має гнучку архітектуру, що дозволяє здійснювати керування як самим виробничим процесом, так і зв'язаними $з$ ним допоміжними процесами, включаючи рівень планування ресурсів підприємства ERP (Enterprise Resource Planning), рівень систем управління виробництвом MES (Manufacturing Execution System), piвень автоматизації управління технологічним процесом, аж до автоматизації польового рівня. Така вертикальна інтеграція, поряд зі скороченням витрат на взаємодію та обмін даними, забезпечує максимальну прозорість на всіх рівнях [2].

Проектування сучасних систем класу АСКТП виробництва з використанням SCADA SIMATIC WINCC характерно для створення нових сучасних підприємств із високим рівнем автоматизації, що відповідає принципу проектування «зверху донизу».

Для більшості «старих» підприємств, що діють у сучасних економічних умовах, такий підхід є занадто затратним 3 урахуванням вартості як програмних так і відповідних технічних засобів. Окрім цього, на протязі останніх років, для багатьох підприємств з обмеженими фінансовими ресурсами, використовується інший принцип проектування АСКТП - так зване проектування «знизу вгору», тобто створення окремих АРМ операторів технологічних ділянок та наступне об’єднання їх з АРМами технічних керівників за допомогою популярних мережних засобів на базі технології Еthernet. Такий підхід дозволяє поступово, згідно до фінансових можливостей, створювати АСКТП підприємства, 3 підключенням нових АРМ операторів, використовуючи при виборі технічних і програмних засобів відомий принцип «ціна - якість».

Таким чином, згідно до традиційного підходу створення АСКТП на підприємстві ЗАМОВНИКА, де остання стратегія провадиться 3 2005-го року потрібно було створити інформаційно-керуючу систему турбінного цеху 3 мінімально можливими затратами на комплекс технічних і програмних засобів.

\section{Мета і завдання дослідження}

У складі АСКТП Красилівського заводу раніше була створена інформаційно-керуюча система котельного відділення, що включає АРМи операторів п'яти котлоагрегатів об'єднаних 3 АРМ начальника ТЕЦ. Система побудована на базі серверної структури з використанням тонких клієнтів і мережі мікропроцесорних контролерів $\mathrm{i}$ регуляторів фірми «МІКРОЛ» українського виробництва. SCADA-система, що використана в системі також $є$ українською розробкою (підприємство «ннотехпром», м. Полтава) [3]. У розробленій системі інформація про роботу турбінного цеху була надана на АРМ начальника ТЕЦ у дуже обмеженому вигляді. Нова інформаційна система повинна була надати більш детальну інформацію про стан основних та допоміжних технологічних процесів турбінного цеху, що суттєво додає персоналу даних для аналізу роботи ТЕЦ в цілому. Тому мета й завдання передпроектних досліджень полягала в зібранні вихідних даних про необхідну для подання інформацію, бажану форму подання цієї інформації, визначення необхідної періодичності опитування даних, котра виключала би втрату інформації, проведенні аналізу можливих варіантів структури системи, алгоритмічних рішень та вибору технічних та програмних засобів для реалізації з остаточним узгодженням основних технічних рішень із технічним керівництвом заводу. Результати розробки потрібно було оформити як технічну документацію, передати ії спеціалістам ЗАМОВНИКА, та надати науково-технічну допомогу для впровадження системи на заводі.

За узгодженим зі спеціалістами ЗАМОВНИКА переліком завдань, більшість контурів регулювання регламентованих змінних турбоцеху, що реалізовані на локальних регуляторах, не підлягає модернізації, бо вони задовольняють вимогам регламенту роботи турбінного цеху. До обладнання даного цеху була віднесена редуційноохолоджувальна установка (РОУ), що забезпечує підготовку гріючої пари для першого корпусу випарної станції (ВС). Як відомо, на перший корпус ВС необхідно подавати насичену пару для найбільш ефективної роботи ВС. Таким чином, окрім інформаційних функцій, система повинна реалізувати функції керування РОУ.

\section{Методи та матеріали досліджень}

У процесі виконання передпроектних досліджень використовувались методи порівняльного аналізу варіантів структури системи із застосуванням різних технічних та програмних засобів. Остаточні рішення приймалися на основі критерію «ціна-якість» із перевіркою працездатності системи методами імітаційного моделювання. У процесі імітаційного моделювання був використаний лабораторний стенд, оснащений промисловими контролерами: МТР-8, МІК-12, аналоговими задатчиками РЗД-22 (зі струмовим виходом 4,..,20 мА), блоком перетворення інтерфейсів БПІ52, комп'ютером із установленим програмним забезпеченням: драйвером для БПI-52, SCADA-системою «IHДЕЛ» с драйвером MODBUS RTU, що надає можливості обміну із контролерами по двохпровідному інтерфейсу RS-485.

Для оцінювання оптимальної періодичності опитування даних, котра виключала би втрату інформації, застосована відома інженерна методика, котра базується на наслідку з теореми Котельникова [4].

\section{Результати дослідження}

Основні остаточні технічні рішення. За результатами передпроектних досліджень була запропонована й узгоджена з ЗАМОВНИКОМ інформаційно-керуюча система у вигляді АРМ оператора, що має структуру, відображену на рис. 1. Комплекс технічних засобів (КТЗ) системи включає мережу мікропроцесорних контролерів у складі: три МТР-8 ; два МIК-12, блок перетворення інтерфейсів БПI-52 (MODBUS RTU - USB), мініатюрний комп'ютер - неттоп типу 3QNTP-D2560. Останній відрізняється мініатюрними розмірами корпусу, що дозволяє 
кріпити його на задній стінці монітора, гальванічне розв'язаним живленням (блок живлення входить в комплект поставки), розвиненим набором інтерфейсних пристроїв зв'язку, включаючи порт Ethernet, USB i iн. Установлена операційна система WINDOWS-XP забезпечує реалізацію всіх функцій SCADA-системи «ІНДЕЛ». Вибір останньої, замість пропонованої виробниками контролерів SCADA-системи «Visual Intellect», обумовлений перш за все простотою й зручністю роботи з налаштування драйвера MODBUS RTU, що входить в комплект поставки SCADAсистеми «ІНДЕЛ», що дозволяє забезпечити зв'язок з усіма контролерами фірми «МІКРОЛ» і досить розвиненими функціональними можливостями, добре знайомими як операторам технологічних ділянок, так і технічним керівникам підприємства, чиї робочі місця оснащені АРМ.

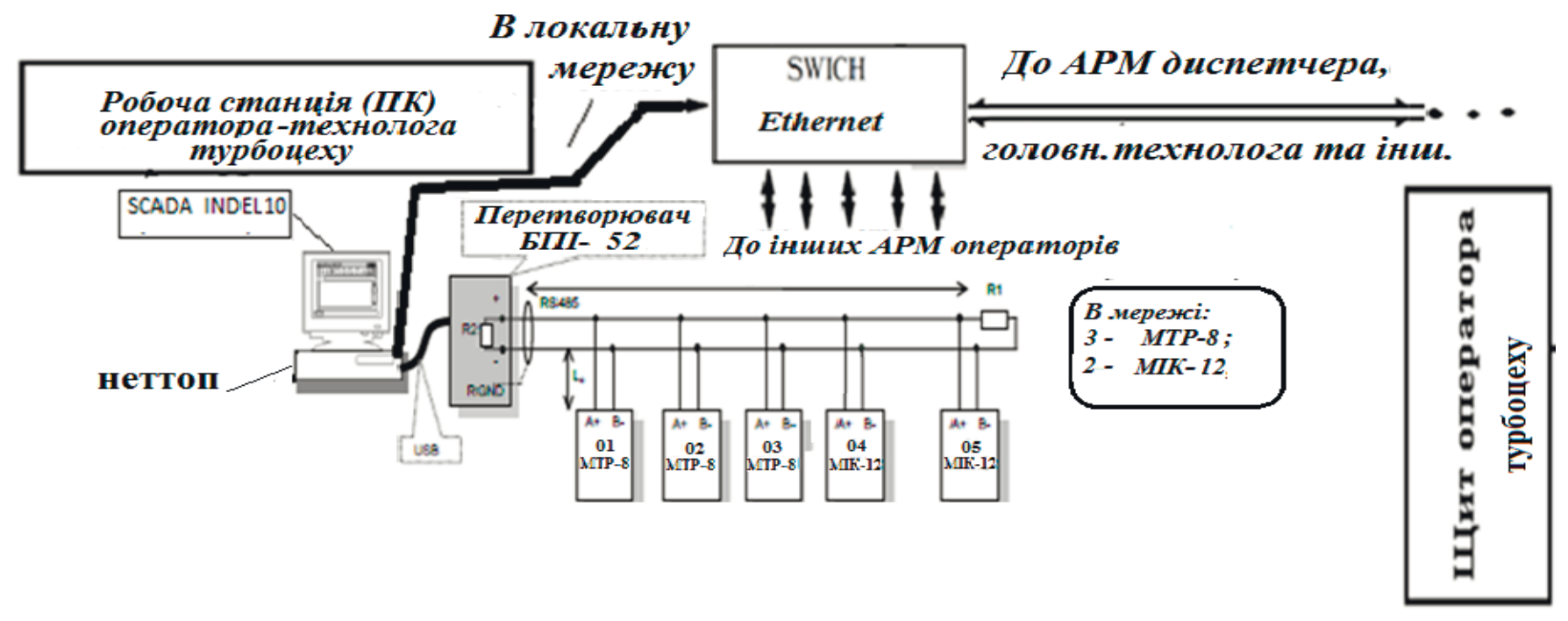

Рис. 1 - Структура АРМ для оператора турбінного цеху

Перелік завдань, реалізованих у складі АСКТП турбоцеху, включає: контроль технологічних змінних процесу (табл. 1) та регулювання (стабілізація) регламентованих змінних (табл. 2).

Таблиця 1 - Перелік змінних, що контролюються в системі

\begin{tabular}{|c|c|c|c|}
\hline №3/ח & Найменування змінної & Діапазон & № регістру \\
\hline 1 & 2 & 3 & 4 \\
\hline \multicolumn{3}{|c|}{ Контролер МТР-8 №1 (мережева адреса - 1) } & \\
\hline 1. & Тиск пари до турбіни 1, атм (номінал) & $0 \ldots 25(21)$ & 1 \\
\hline 2. & Тиск пари перед стопорним клапаном 1, атм (номінал) & $0 \ldots 25(21)$ & 2 \\
\hline 3. & Тиск пари в регулюючому щаблі 1, атм (номінал) & $0 \ldots 25(21)$ & 3 \\
\hline 4. & Протитиск пари на виході з турбіни 1, атм & $0 \ldots 4$ & 4 \\
\hline 5. & Тиск масла 1, атм (номінал) & $0 \ldots 10(7)$ & 5 \\
\hline 6. & Тиск інжектор 1 (масло), атм (номінал) & $0 \ldots 4(1,5)$ & 6 \\
\hline 7. & Тиск масла НА ЗМАЩЕННЯ 1, атм (номінал) & $0 \ldots 4(1,5)$ & 7 \\
\hline 8. & Температура масла НА ЗМАЩЕННЯ $1,{ }^{\circ} \mathrm{C}$ (номінал) & $0 \ldots 150(60)$ & 8 \\
\hline \multicolumn{3}{|c|}{ Контролер МТР-8 МТР-8 №2 (мережева адреса -2) } & \\
\hline 1. & Тиск пари до турбіни 2, атм (номінал) & $0 \ldots 25(21)$ & 1 \\
\hline 2. & Тиск пари перед стопорним клапаном 2, атм (номінал) & $0 \ldots 25(21)$ & 2 \\
\hline 3. & Тиск пари в регулюючому щаблі 2, атм (номінал) & $0 \ldots 25(21)$ & 3 \\
\hline 4. & Протитиск пари на виході з турбіни 2, атм & $0 \ldots 4$ & 4 \\
\hline 5. & Тиск масла 2, атм (номінал) & $0 \ldots 10(7)$ & 5 \\
\hline 6. & Тиск інжектор 2 (масло), атм (номінал) & $0 \ldots 4(1,5)$ & 6 \\
\hline 7. & Тиск масла НА ЗМАЩЕННЯ 2, атм (номінал) & $0 \ldots 4(1,5)$ & 7 \\
\hline 8. & Температура масла НА ЗМАЩЕННЯ 2, ${ }^{\circ} \mathrm{C}$ (номінал) & $0 \ldots 150(60)$ & 8 \\
\hline
\end{tabular}


Продовження таблиці 1

\begin{tabular}{|l|l|c|c|}
\hline \multicolumn{1}{|c|}{ Контролер МТР-8 №3 (мережева адреса -3$)$} & 3 & 4 \\
\hline \multicolumn{1}{|c|}{ Ко } & \\
\hline 1. & Витрата пари на турбіну 1, т/г & $0 \ldots 32$ & 1 \\
\hline 2. & Температура пари після турбіни $1,{ }^{\circ} \mathrm{C}$ & $0 \ldots 350$ & 2 \\
\hline 3. & Витрата пару на турбіну 2, т/Г & $0 \ldots 32$ & 3 \\
\hline 4. & Температура пари після турбіни 2, ${ }^{\circ} \mathrm{C}$ & $0 \ldots 350$ & 4 \\
\hline 5. & Тиск води, атм & $0 \ldots 4$ & 5 \\
\hline 6. & Витрата пари на РОУ, т/г & $0 \ldots 25$ & 6 \\
\hline 7. & Температура пари до РОУ & $0 \ldots 400$ & 7 \\
\hline
\end{tabular}

Таблиця 2 - Перелік змінних, що контролюються та регулюються в системі

\begin{tabular}{|c|c|c|c|}
\hline №3/ח & Найменування змінної та керуючої дії & Діапазон & № pегістру \\
\hline \multicolumn{3}{|c|}{ Контролер МІК-12 №1 (мережева адреса -4) } & \\
\hline 1. & Тиск пари на 1 корпус ВС, атм & $0 \ldots 4$ & 1 \\
\hline 2. & Положення ВМ подачі пари на 1 корпус ВС, \% & $0 \ldots 100$ & 6 \\
\hline \multicolumn{3}{|c|}{ Контролер МІК-12 №2 (мережева адреса -5) } & \\
\hline 1. & Температура пари після РОУ, ${ }^{\circ} \mathrm{C}$ & $0 \ldots 400$ & 1 \\
\hline 2. & Положення ВМ вприскування охолоджувальної води , \% & $0 \ldots 100$ & 6 \\
\hline
\end{tabular}

Таким чином, у системі відображаються 25 змінних, з яких 2 є регульованими в даній системі. Дослідження найменш інерційної змінної («Протитиск пари на виході з турбіни 1») дозволило визначити період опитування даних, що дозволяє не втрачати інформацію. На рис. 2 наведена форма налаштування сервера APM iз драйвером MODBUS, де використане отримане настроювання «Період запитів» - 500 мс.

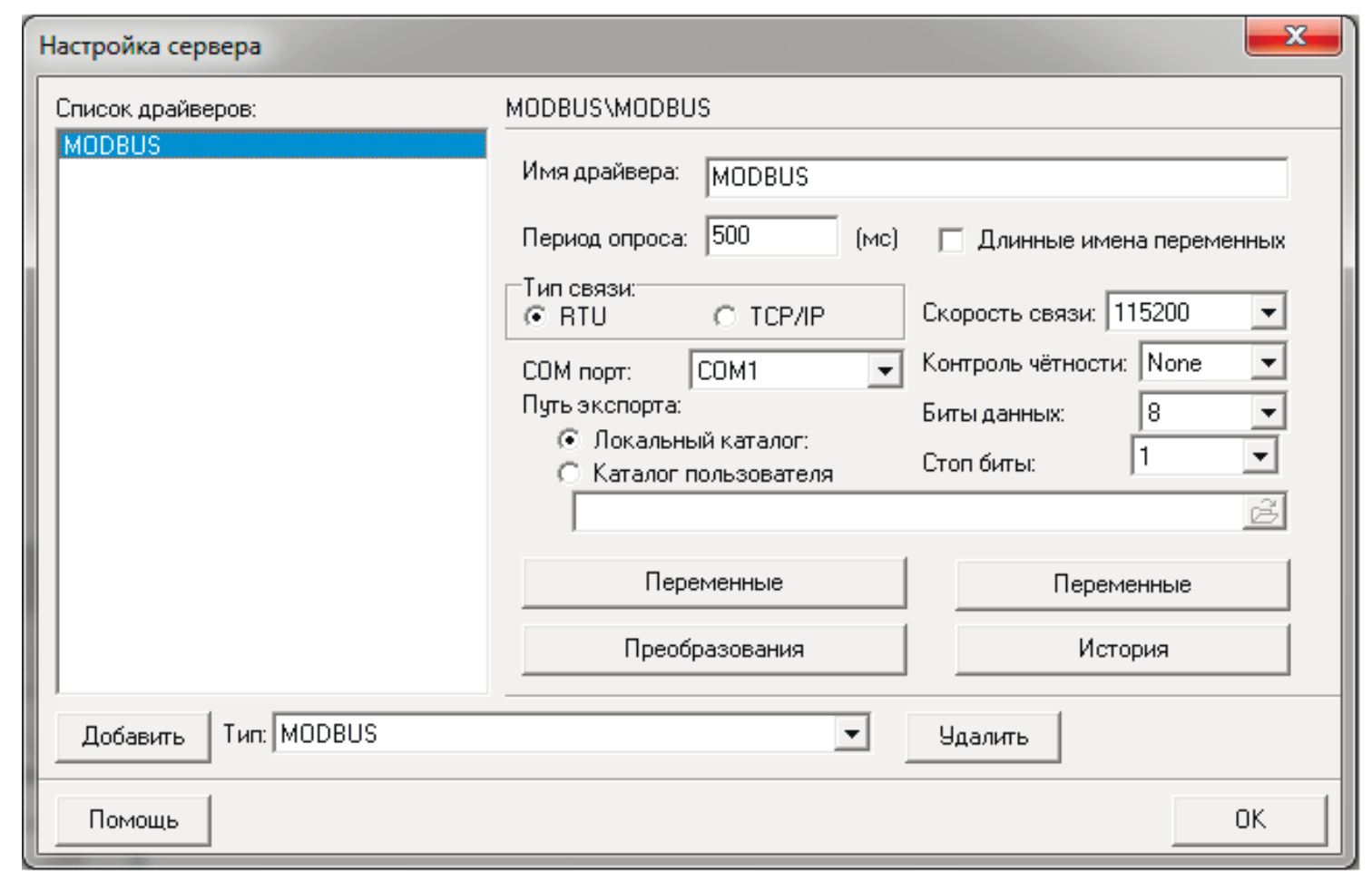

Рис. 2 - Форма налаштування сервера АPM із драйвером MODBUS

На рис. 3 наведена основна екранна форма АРМ оператора, де відображені змінні, що контролюються та регулюються. Форма відображає процес перевірки працездатності АРМ на імітаційному стенді. Оскільки на стенді одночасно неможливо перевіряти працездатність усіх інформаційних каналів, перевірка здійснювалась послідовно для груп сигналів та окремих функцій. 
На рис. 4 наведена форма налаштування драйвера MODBUS, де відображені його настроювання: адреса контролера в мережі, імена змінних, типи даних, що використовуються, номера регістрів (зміщення початку даних) і iн.

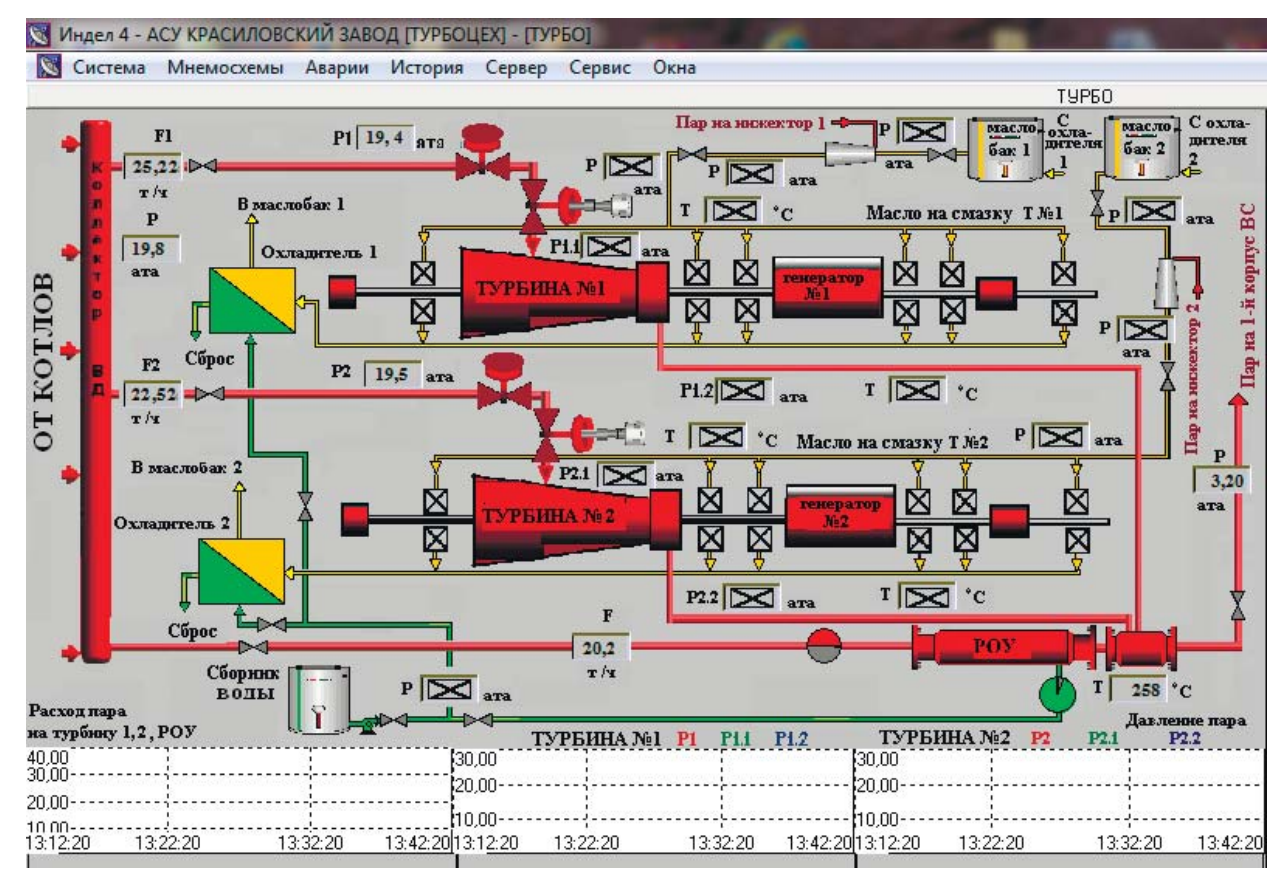

Рис. 3 - Основна екранна форма АРМ оператора турбоцеху

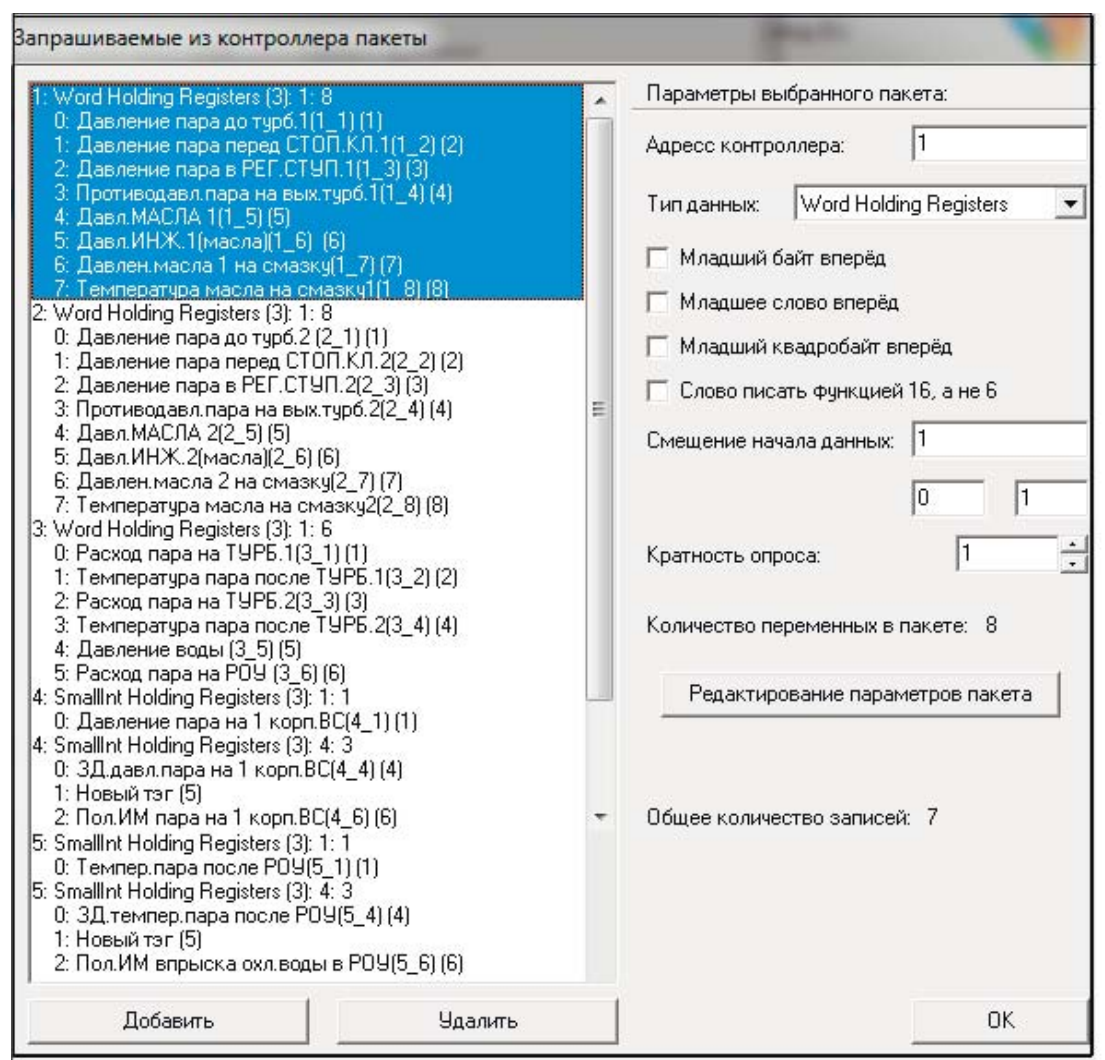

Рис. 4 - Форма налаштування драйвера MODBUS

У кожному імені змінних для зручності роботи під час налагодження та експлуатації системи додана мережна адреса контролера та відповідний номер регістра. 
Модернізація системи супроводжувалась оновленням парку датчиків. На турбінах встановлені датчики тиску українського виробництва типу «Мікротерм МТМ-700ДИ», призначені для вимірювання високих тисків необхідного діапазону.

Розроблена інформаційно-керуюча система включена до складу АСКТП ТЕЦ і, відповідно входить в АСКТП цукрового заводу.

\section{Обговорення результатів}

Впровадження інформаційно-керуючої системи турбінного цеху дозволило, сумісно з інформаційною системою котельного відділення, надавати, як оператору, так і технічному керівництву (начальнику ТЕЦ, теплотехніку, головному інженеру) оперативну достовірну інформацію про функціонування обладнання та поведінку контрольованих змінних технологічних процесів (ТП) ТЕЦ. Аналіз поведінки ТП ТЕЦ сумісно з інформацією про ТП $\mathrm{BC}$, яка $\epsilon$ основним споживачем теплової енергії, дозволило за результатами об'єктивного оцінювання приймати своєчасні рішення 3 коректування режимів роботи енерговитратного встаткування, що у свою чергу, дозволило знизити питомі витрати палива (природного газу). Наявність розвинутого функціонала в SCADA-системі «IHДЕЛ», українського виробництва, а саме можливість архівації даних із наступним роздрукуванням, як динамічних так і параметричних графіків змінних, фіксації передаваріних станів, видачі мовних повідомлень і інш., полегшує проведення необхідного сумісного аналізу ТП на суміжних технологічних ділянках (відділеннях).

В результаті проведених робіт із передпроектних досліджень, розробки та впровадження інформаційно-керуючої системи турбінного цеху підтверджена доцільність використання принципу проектування АСКТП «знизу вгору», для підприємств, що не мають достатніх фінансових можливостей для одночасних суттєвих витрат на розробку АСКТП.

\section{Висновки}

Проведені передпроектні дослідження з використанням методів імітаційного моделювання на спеціалізованому стенді, котрий було обладнано промисловим устаткуванням: контролерами та регуляторами, комп'ютером з SCADAсистемою «ІНДЕЛ», українського виробництва, дозволили розробити комплекс технічних рішень, що забезпечує успішну експлуатацію інформаційно-керуючої системи турбінного цеху в складі АСКТП цукрового заводу. Основна складова ефективності системи полягає в зменшенні питомих витрат енергоносіїв.

Технічні й програмні засоби Українського виробництва забезпечують точність підтримання регламентів ведення процесу, досить комфортні умови, як оперативному персоналу, так і технічним керівникам підприємства для аналізу ТП. Виконаний комплекс робіт дозволяє зробити висновок про доцільність продовження робіт із модернізації систем керування підприємства, використовуючи принцип проектування АСКТП - «знизу вгору», а також наведені методи й підходи до прийняття основних технічних рішень.

\section{Список використаних джерел}

[1] Жуковський Е.Й. Багаторівнева АСУТП цукрового заводу/ Е.Й. Жуковський, Ю.М. Скаковський, В.Д. Витвицький, А.В. Бабков//Докл. 18 міжнар. конф. 3 автоматичного управління „АВТОМАТИКА-2011” 28-30 вересня 2011, Львів, Україна, -Львів: Вісник НУ «Львівська політехніка», 2011 - С.256-257.

[2] URL: https://w5.siemens.com/web/ua/ru/iadt/about/references/gaz/broschures/Documents/Simatic_PCS7.pdf （дата звернення: 17.06.2018).

[3] Скаковський Ю. М. Використання технології «тонких клієнтів» для створення інформаційної системи котельного відділення в ТЕЦ цукрозаводу /Ю. М. Скаковський, А. В. Бабков//Автоматизація технологічних і бізнес-процесів. - Одеса: 2014 - №17, С. 8-10.

[4] Трегуб В.Г. Наладка и эксплуатация систем автоматизации пищевых производств/В.Г. Трегуб, А.В.Терновный. Киев: Техніка, 1978. -318 с.

\section{References}

[1] Zhukovs`ky`j E.J. Bagatorivneva ASUTP czukrovogo zavodu/ E.J. Zhukovs`ky`j, Yu.M. Skakovs`ky`j, V.D. Vy`tvy`cz ky`j, A.V. Babkov//Dokl. 18 mizhnar. konf. z avtomaty`chnogo upravlinnya „AVTOMATY`KA-2011” 28-30 veresnya 2011, L`viv, Ukray`na, -L`viv: Visny`k NU «L`vivs`ka politexnika», 2011 - S.256-257.

[2] URL:https://w5.siemens.com/web/ua/ru/iadt/about/references/gaz/broschures/Documents/Simatic_PCS7.pdf (data zvernennya: 17.06.2018).

[3] Skakovs`ky`j Yu.M. Vy`kory`stannya texnologiyi «tonky`x kliyentiv» dlya stvorennya informacijnoyi sy`stemy` kotel`nogo viddilennya $\mathrm{v}$ TECz czukrozavodu /Yu. M. Skakovs`ky`j, A. V. Babkov//Avtomaty`zaciya texnology`chny`x i biznes-procesiv. - Odessa: 2014 - \#17, S. 8-10.

[4] Tregub V.G. Naladka i ekspluatatsiya sistem avtomatizatsii pishchevykh proizvodstv/V.G. Tregub. A.V.Ternovnyy. ᄀ Kiyev: Tekhnika. 1978. -318 s. 